\title{
Comparison of two validated gas-chromatographic methods for the determination of trihalomethanes in drinking water
}

\author{
Maria Yumiko Tominaga', Antonio Flavio Mídio ${ }^{2 *}$ \\ ${ }^{1}$ CETESB - Cia de Tecnologia de Saneamento Ambiental, São Paulo,Brasil, ${ }^{2}$ Departamento de Análises Clínicas e \\ Toxicológicas-Toxicologia, Faculdade de Ciências Farmacêuticas, Universidade de São Paulo
}

*Correspondence:

A. F. Mídio

Departamento de Análises Clínicas e

Toxicológicas

Faculdade de Ciências Farmacêuticas

Universidade de São Paulo

Av. Prof. Lineu Prestes, 580

05508-900 - S. Paulo - Brasil

E -mail: afmidio@usp.br
In this paper the results obtained using two validated gaschromatographic procedures on drinking water for the determination of trihalomethanes are compared. The volatile compounds, chloroform (CF), bromodichloromethane (BDCM), dibromochloromethane (DBCM) and bromoform $(B F)$ were detected by purge and trap capillary column gas-chromatography with electrolytic conductivity detector (ELCD) and the simple and rapid gas-chromatographic method by electron capture detector (ECD) after liquid-liquid extraction with n-pentane. For purge and trap ELCD method the response for the volatile compounds was linear for the concentrations of 0.5 to $40 \mu \mathrm{g} / \mathrm{L}$. For liquid-liquid extraction ECD method the response was linear for the concentrations of 0.5 to $100 \mu \mathrm{g} / \mathrm{L}$. The comparison of both methods was achieved by analyzing samples of drinking water collected in the city of São. Paulo, Brazil. The ratios of concentrations obtained by the two methods (ECD/ELCD) were as follows: $1.13 \pm 0.9$ for chloroform; $0.93 \pm 0.15$ for BDCM and $0.92 \pm 0.17$ for DBCM. Bromoform was not detected in the drinking water samples. The ratio of $1.08 \pm 0.047$ for total triahalomethane - THMt (the sum of the three compounds) shows the equivalence of the compared methods.
Uniterms:

- Trihalomethanes

- Gas-chromatographic detection

- Comparison of methods

- Drinking water

\section{INTRODUCTION}

Man ingests water in a quantity much bigger than all other foods together and it constitutes his main excretion as well. An adult ingests more than two liters of water a day, about $3 \%$ of his weight, which is composed of more than $80 \%$ of water (Riedel, 1992).

This extraordinary contact with water justifies and explains how easily macro and microscopic parasites present in water reach and develop in man when some other factors are favorable to their living and multiplication (Tominaga, Mídio, 1999).

On the other hand, man is exposed to chemical contaminants that are present in natural waters. It is supposed that 4.0 billions of cubic meters of chemical contaminants from industrial and domestic effluents as well 
as agricultural chemicals reach the soil and consequently the water each year (Wang, 1994). A series of chemical and physical transformations including combinations with other chemicals increase their toxicity to men and other living organisms ( Tominaga, Mídio, 1999).

All these risk factors may be controlled by treating natural waters with chemicals which may also generate other public health problems. Chlorine and its compounds are the chemical agents of choice once they can effectively destroy or inactivate parasite organisms. Besides, they are easily employed and detected in water offering residues which protect water from further biological contamination (Dychdala,1983)

Chlorinated waters, however, may present byproducts which represent a certain risk of health significance to human population (Singer, 1993). They are produced by the reaction of free chlorine used in the disinfection and certain organic substances (humic and fulvic compounds) present in natural waters. Table I shows the main halogenated by-products present in chlorinated waters and among them the most important ones named trihalomethanes (THM) (Singer, 1993).

TABLE I - By-products present in drinking water treated with chlorine

\begin{tabular}{|c|c|}
\hline $\begin{array}{l}\text { Trihalometanes } \\
\text { chloroform } \\
\text { bromodichloromethane } \\
\text { dibromochloromethane } \\
\text { bromoform }\end{array}$ & $\begin{array}{l}\text { Haloacetic acids } \\
\text { monochloroacetic acid } \\
\text { dichloroacetic acid } \\
\text { trichloroacetic acid } \\
\text { monobromoacetic acid } \\
\text { dibromoacetic acid } \\
\text { bromochloroacetic acid }\end{array}$ \\
\hline $\begin{array}{l}\text { Cyanogenic halides } \\
\text { cyanogenic chloride } \\
\text { cyanogenic bromide }\end{array}$ & $\begin{array}{l}\text { Haloacetonitriles } \\
\text { dichloroacetonitrile } \\
\text { trichloroacetonitrile }\end{array}$ \\
\hline $\begin{array}{l}\text { Halopicrines } \\
\text { chloropicrin } \\
\text { bromopicrin }\end{array}$ & $\begin{array}{l}\text { dibromoacetonitrile } \\
\text { tribromoaetonitrile } \\
\text { bromochloroacetonitrile }\end{array}$ \\
\hline Chloral hydrates & $\begin{array}{l}\text { Haloacetones, } \\
\text { Haloaldehydes, } \\
\text { Halophenols }\end{array}$ \\
\hline
\end{tabular}

It was only at the beginning of the seventies that chloroform and other trihalomethanes (bromodichloromethane, dibromochloromethane and bromoform) were detected in drinking water and considered, by far, the most important by-products in the chlorination of natural water due to the discovery of the carcinogenicity of chloroform in a bioassay of the National Cancer Institute (Singer, 1993). In 1979 the United States Environmental Protection Agency (USEPA) proposed a maximum allowable concentration of $100 \mathrm{mg}$ of total trihalomethanes (THMt) per liter of potable water (USEPA, 1979; Singer, 1993; Richardson, 1998). More recently, however, the maximum contaminant level was lowered to $80 \mathrm{mg} / \mathrm{L}$ (Pontius, 1997).

Epidemiological studies have been designed, specially in the United States, to evaluate the presence of THM in drinking water and its correlation with cancer production in experimental animals and humans (Page et al., 1976; Bull, 1982; Young et al., 1987; Cech et al., 1993; Craun, 1993). However, little is known about the real effect of these compounds in low concentrations in drinking water $(\mu \mathrm{g} / \mathrm{L}, \mathrm{ng} / \mathrm{L})$ to the human population. Experimental studies have shown that the sub-products of water chlorination are carcinogenic to animals in concentrations much higher than those found in the water for human consumption (WHO,1994; WHO, 1996). Nevertheless the theory that there is a high probability of the relationship between cancer of urinary bladder, colon and rectum and the exposure to THM in drinking water is well accepted (Menzer, 1991; WHO,1993; WHO,1994; Richardson,1998; WHO,1996).

Trihalomethanes have been determined in drinking water by liquid-liquid extraction and gas-chromatography with electron capture detection (ECD), static headspace system and dynamic headspace (purge and trap) with ECD, electrolytic conductivity and mass-spectrometry (Oliver, 1989). Purge and trap technique is the most employed in the United States while in Europe the static headspace system is mostly used (USEPA, 1979; APHA, 1995).

Despite of the obvious advantages of the large number of analytical procedures the volatility of the compounds are still prone to problems associated with sample preparation, quality of reagents, laboratory devices, special equipment together with analyte losses and potential errors.

The purpose of this work was to evaluate the advantages in sensitivity and accuracy of two validated chromatographic methods associated with the determination of trihalomethanes in drinking water.

\section{MATERIAL AND METHODS}

\section{MATERIAL}

\section{Instrumentation}

A Hewlett Packard gas-chromatograph, model 5730 , equipped with electron capture detector (ECD), 
$\mathrm{Ni}^{63}$; a Hewlett Packard integrator, model 3390 and a 6 feet glass column ( $2 \mathrm{~mm}$ id), packed with $10 \%$ esqualane in Chromossorb WAW (80-100 mesh) were used for method A.

A Varian gas-chromatograph, model Star 3400 CX, equipped with a Tremetrics electrolytic conductivity detector (ELCD), model 1000; a Teckmar purge and trap system (automatic sampler model 2016 and a sample concentrator model 3000); a Supelco pre-concentration column; a Hitachi integrator model D-200 and a J\&W Scientific DD-624 capillary column $(30 \mathrm{~m}, 0.53 \mathrm{~mm}$ id and $3 \mathrm{~mm}$ film thickness) were used for method B.

So as not to contaminate all glassware and any other material used in the analyses (made of pyrex and/or silicon) were washed with diluted nitric acid solution, rinsed with distilled deionized water freed from organic interfering compounds by boiling for $60 \mathrm{~min}$ and purged with $\mathrm{He}$ for $15 \mathrm{~min}$.

\section{Reagents}

All reagents were of analytical grade. Methanol (Carlo Erba) and $n$-pentane (Fischer) were HPLC grade. Anhydrous sodium sulphite (Synth) was pro-analysis grade. Trihalomethane mixture: $1 \mathrm{~mL}$ ampoule containing $200 \mu \mathrm{g}$ of each compound (Supelco - catalog N-4-8746). Standard solutions of trihalomethanes were prepared with a mixture of chloroform (CF), bromodichloromethane (BDCM), dibromochloromethane (DBCM) and bromoform (BF) containing $20 \mu \mathrm{g} / \mathrm{mL}$ of each compound in methanol.

Internal standards: 1-bromobutane ( Merck) and 1chlor-2-bromopropane $(100 \mu \mathrm{g} / \mathrm{mL})$ in methanol (Supelco catal.N4-8713).

\section{Blank water}

The production of blank water for the analyses of volatile organochloride compounds in drinking water was achieved by distilling, deonizing and boiling it for $60 \mathrm{~min}$ and finally purging it with $\mathrm{He}$ for $15 \mathrm{~min}$.

\section{Sampling}

The samples used in this work were obtained in the following manner: 20 samples of drinking water were collected at different times and conditions from several parts of the city of São Paulo, Brazil. To collect the water the tap was open wide and the water was let to flow freely till the temperature was constant. The flow was then adjusted to $500 \mathrm{~mL} / \mathrm{min}$ and the water was received in a $125 \mathrm{~mL}$ borosilicate glass vial containing about $0.2 \mathrm{~g}$ of anhydrous sodium sulfite. The vials were closed hermetically with no headspace formation and maintained at $4{ }^{\circ} \mathrm{C}$ until analyses took place.

\section{Methods}

\section{Method 1. Determination of trihalomethanes by means of liquid-liquid extraction and electron capture detection (ECD) gas-chromatography}

The water sample was transferred to a separatory funnel and $5 \mu \mathrm{L}$ of internal standard (1-bromobutane $1.015 \mathrm{mg} / \mathrm{L})$ were added. A $25 \mathrm{~mL}$ flask with a polyethylene cap was totally filled with the water sample. With a hypodermic syringe $5 \mathrm{~mL}$ of the sample were drained. With another hypodermic syringe $4 \mathrm{~mL}$ of $n$ pentane were transferred to the flask. The mixture was shaken thoroughly for $1 \mathrm{~min}$ and the layers were let to separate. The organic phase $(2 \mathrm{~mL})$ was then injected in the chromatographic system with ECD in the following conditions: temperatures: oven $=70{ }^{\circ} \mathrm{C}$ (isothermal); injection port $=100{ }^{\circ} \mathrm{C}$ and detector $=250{ }^{\circ} \mathrm{C}$. Nitrogen carrier flow of $20 \mathrm{~mL} / \mathrm{min}$.

\section{- Validation of the method}

Calibration curves and linearity were performed in blank water samples in which trihalomethanes and internal standard $(1.015 \mu \mathrm{g} / \mathrm{L})$ were spiked to obtain concentration ranges from 0.5 to $10 \mu \mathrm{g} / \mathrm{L}$ and from 10 to $100 \mu \mathrm{g} / \mathrm{L}$. Curves were constructed by plotting peak-area ratios of trihalomethanes to internal standard as a function of the compounds concentrations. The equations of the calibration lines were calculated by least-squares linear regression and was used to calculate the concentration of each trihalomethane in the unknowns. Routine quality control was assessed by use of in-house trihalomethane controls analyzed in each run. Quality control (QC) samples used to assess within and between-day precision were freshly prepared and assayed with each calibration curve.

Precision, accuracy and recovery tests were determined in triplicate by spiking trihalomethane-free water samples with known amounts of the compounds at concentrations of $2.0 ; 4.0 ; 10.0 ; 20.0$ and $40.0 \mu \mathrm{g} / \mathrm{L}$ and internal standard. The samples were extracted and analyzed in triplicates as described above.

Method 2. Determination of trihalomethanes by purge and trap capillary column gas-chromatography with electrolytic conductivity detector (ELCD)

The water sample was transferred to a $50 \mathrm{~mL}$ volumetric flask in which $5 \mu \mathrm{L}$ of the internal standard 
solution (1-chloro-2-bromopropane) was added. By means of a high performance syringe for gases (Tefloncoated plungers) $5 \mathrm{~mL}$ of the mixture was transferred to the automatic sampler of the purge and trap system. The sample was purged for $11 \mathrm{~min}$ and dessorbed at $180^{\circ} \mathrm{C}$ for 4 minutes to the gas chromatograph with ELCD in the following conditions: temperatures of the oven: $40{ }^{\circ} \mathrm{C}$ (initial) and $200{ }^{\circ} \mathrm{C}$ (final); temperature of the injector $=$ $200^{\circ} \mathrm{C}$; temperature of the detector $=250^{\circ} \mathrm{C}$; temperature of the reactor $=840^{\circ} \mathrm{C}$. Electrolyte $(n$-propanol) flow $=$ $0.6 \mathrm{~mL} / \mathrm{min}$; hydrogen flow $=30 \mathrm{~mL} / \mathrm{min}$; helium flow in the column $=6 \mathrm{~mL} / \mathrm{min}$ and $30 \mathrm{~mL} / \mathrm{min}$ in the detector.

- Validation of the method

Calibration curves and linearity were performed in $5 \mathrm{~mL}$ blank water samples in which trihalomethanes and internal standard (1-chloro-2-bromopropane $=10 \mu \mathrm{g} / \mathrm{L}$ ) were spiked to obtain concentration ranges from 0.1 to $40 \mu \mathrm{g} / \mathrm{L}$. They were constructed by plotting peak-area ratios of trihalomethanes to internal standard as a function of the compound concentrations. The equations of the calibration lines were calculated by least-squares linear regression and were used to calculate the concentration of each trihalomethane in the unknowns. Routine quality control (QC) was assessed by use of in-house trihalomethane controls analyzed in each run. Quality control (QC) samples used to assess within and between-day precision were freshly prepared and assayed with each calibration curve.

Precision, accuracy and recovery tests were determined in triplicate by spiking trihalomethane-free water samples with known amounts of the compounds, at concentrations of $2.0 ; 4.0 ; 10.0 ; 20.0$ and $40.0 \mu \mathrm{g} / \mathrm{L}$ and internal standard. The samples were analyzed in triplicates as described above.

\section{RESULTS AND DISCUSSION}

Both methods showed good linearity in the concentration ranges: $0.5-10$ and $10-100 \mu \mathrm{g} / \mathrm{mL}$ for all trihalomethanes for Method 1 and $0.5-40 \mu \mathrm{g} / \mathrm{mL}$ for Method 2. Limits of detection (LOD) and limits of quantification (LOQ) for both methods were obtained according to Miller and Miller (1988) and are presented in Table II.

Accuracy expressed as bias (\%) precision and recovery for Methods 1 and 2 are presented in Tables III and IV respectively. For gas-chromatographic purposes accuracy (bias) up to $20 \%$ of the real value and a precision (coefficient of variation- CV) lower than $15 \%$ are accepted (Causon, 1997).

Values for CV obtained when Method 1 was applied (Table III) showed good precision for the detection of the four trihalomethanes. The higher value of $\mathrm{CV}$ obtained was $3.6 \%$ for chloroform spiked in the concentration of $4 \mu \mathrm{g} / \mathrm{L}$. The method was also considered accurate with the only exception of bromoform in the concentration of $10 \mu \mathrm{g} / \mathrm{L}$ when a bias of $+23 \%$ was found. Recoveries for Method 1 were around $100 \%$ for all THM studied in all spiked concentrations.

When Method 2 was used, (Table IV) capillary gaschromatography produced obviously better separation of the compounds. Values obtained for CV showed that the purge and trap technique and detection with ELCD presented good precision for the determination of the four THM. The higher CV obtained (10.2\%) was for chloroform spiked in the sample in the concentration of $2.00 \mu \mathrm{g} / \mathrm{L}$. This method is also accurate; the higher bias between spiked and found concentrations was $+6,0 \%$ for bromodichloromethane in the concentration of $20 \mu \mathrm{g} / \mathrm{L}$.

Trihalomethanes were analyzed by both methods in 20 samples of drinking water of different sources distributed to the population of the city of São Paulo, Brazil. The samples were collected, preserved (with sodium sulfite) and stored at $4{ }^{\circ} \mathrm{C}$ until analyzed (Ho,1988). The samples showed to be stable for 35 days or more if stored in the temperature cited above.

The ratios of THM concentrations were determined to assess the comparison of the two methods. Data from the analyses are summarized in Table V. Bromoform was

TABLE II - Limits of detection (LOD) and quantification (LOQ) of trihalomethanes for Methods 1 and 2

\begin{tabular}{lcccc}
\hline \multirow{2}{*}{ Compound } & \multicolumn{2}{c}{ Method 1 (ECD) } & \multicolumn{2}{c}{ Method 2 (ELCD) } \\
Chloroform & LOD $(\mu \mathrm{g} / \mathrm{mL})$ & LOQ $(\mu \mathrm{g} / \mathrm{mL})$ & LOD $(\mu \mathrm{g} / \mathrm{mL})$ & LOQ $(\mu \mathrm{g} / \mathrm{mL})$ \\
Bromodichloromethane & 0.41 & 1.37 & 0.22 & 0.74 \\
Dibromochloromethane & 1.17 & 3.90 & 0.12 & 0.40 \\
Bromoform & 0.68 & 2.26 & 0.21 & 0.70 \\
\hline
\end{tabular}


TABLE III - Accuracy, precision and recoveries of Method 1 (ECD) in samples of drinking water (blanks) spiked with the four compounds

\begin{tabular}{cccccr}
\hline Compound & $\begin{array}{c}\text { Spiked } \\
\text { concentration } \\
(\mu \mathrm{g} / \mathrm{L})\end{array}$ & $\begin{array}{c}\text { Mean concentration* } \\
\text { detected } \\
(\mu \mathrm{g} / \mathrm{L})\end{array}$ & $\begin{array}{c}\mathrm{CV} \\
(\%)\end{array}$ & $\begin{array}{c}\text { Recovery }(\%) \\
\text { mean } \pm \mathrm{sd}\end{array}$ & $\begin{array}{c}\text { Bias } \\
(\%)\end{array}$ \\
\hline $\mathrm{CF}$ & 2.00 & $2.40 \pm 0.07$ & 0.3 & $120.2 \pm 3.1$ & 20.0 \\
& 4.00 & $4.58 \pm 0.16$ & 3.6 & $114.5 \pm 4.1$ & 14.5 \\
$\mathrm{BDCM}$ & 20.0 & $20.3 \pm 0.10$ & 0.5 & $101.7 \pm 0.5$ & 1.5 \\
& 40.0 & $39.5 \pm 0.82$ & 2.1 & $98.8 \pm 2.0$ & -1.2 \\
& 2.00 & $2.34 \pm 0.03$ & 1.34 & $117.3 \pm 1.6$ & 17.0 \\
$\mathrm{DBCM}$ & 4.00 & $3.98 \pm 0.07$ & 1.8 & $99.6 \pm 1.8$ & -0.5 \\
& 10.0 & $11.0 \pm 0.21$ & 1.9 & $110.5 \pm 2.1$ & 10.0 \\
& 20.0 & $21.0 \pm 0.15$ & 0.7 & $105.3 \pm 0.7$ & 5.0 \\
& 40.0 & $43.1 \pm 0.64$ & 1.5 & $107.9 \pm 1.6$ & 7.7 \\
$\mathrm{BF}$ & 2.00 & $2.1 \pm 0.04$ & 1.9 & $102.8 \pm 2.0$ & 5.0 \\
& 4.00 & $3.6 \pm 0.05$ & 1.4 & $89.5 \pm 1.3$ & -10.0 \\
& 10.0 & $12.0 \pm 0.12$ & 1.0 & $120.3 \pm 1.2$ & 20.0 \\
& 20.0 & $20.2 \pm 0.19$ & 1.0 & $100.9 \pm 1.0$ & 1.0 \\
& 40.0 & $41.6 \pm 0.52$ & 1.2 & $103.9 \pm 1.3$ & 4.0 \\
& 2.00 & $2.2 \pm 0.04$ & 1.8 & $110.4 \pm 2.0$ & 10.0 \\
& 4.00 & $4.0 \pm 0.07$ & 1.7 & $101.1 \pm 1.7$ & 0.0 \\
& 10.0 & $12.3 \pm 0.16$ & 1.3 & $123.2 \pm 1.6$ & 23.0 \\
\hline
\end{tabular}

* three determinations; $\mathrm{CV}=$ coefficient of variation; $\mathrm{sd}=$ standard deviation

TABLE IV - Accuracy, precision and recoveries of Method 2 (ELCD) in samples of drinking water (blanks) spiked with the compounds

\begin{tabular}{cccccr}
\hline Compound & $\begin{array}{c}\text { Spiked } \\
\text { concentration } \\
(\mu \mathrm{g} / \mathrm{L})\end{array}$ & $\begin{array}{c}\text { Mean concentration* } \\
\text { detected } \\
(\mu \mathrm{g} / \mathrm{L})\end{array}$ & $\begin{array}{c}\mathrm{CV} \\
(\%)\end{array}$ & $\begin{array}{c}\text { Recovery }(\%) \\
\text { mean } \pm \mathrm{sd}\end{array}$ & $\begin{array}{c}\text { Bias } \\
(\%)\end{array}$ \\
\hline $\mathrm{CF}$ & 2.00 & $2.05 \pm 0.21$ & 10.2 & $102.5 \pm 10.4$ & 2.5 \\
& 4.00 & $3.83 \pm 0.05$ & 1.28 & $95.9 \pm 1.2$ & -4.2 \\
$\mathrm{BDCM}$ & 10.0 & $9.67 \pm 0.22$ & 2.24 & $96.9 \pm 2.2$ & -3.3 \\
& 20.0 & $18.9 \pm 0.48$ & 2.53 & $94.7 \pm 2.4$ & -5.5 \\
& 2.00 & $1.93 \pm 0.08$ & 4.28 & $96.5 \pm 4.1$ & -3.5 \\
$\mathrm{DBCM}$ & 4.00 & $3.78 \pm 0.08$ & 2.15 & $94.5 \pm 2.0$ & -5.5 \\
& 10.0 & $9.92 \pm 0.13$ & 1.29 & $99.2 \pm 1.3$ & -0.8 \\
& 20.0 & $18.8 \pm 0.40$ & 2.13 & $94.1 \pm 2.0$ & -6.0 \\
$\mathrm{BF}$ & 2.00 & $1.95 \pm 0.16$ & 8.11 & $97.5 \pm 7.9$ & -2.5 \\
& 4.00 & $3.95 \pm 0.10$ & 2.62 & $98.7 \pm 2.6$ & -1.2 \\
& 10.0 & $9.86 \pm 0.23$ & 2.31 & $98.6 \pm 2.3$ & -1.4 \\
& 20.0 & $19.1 \pm 0.49$ & 2.59 & $95.3 \pm 2.5$ & -4.5 \\
& 2.00 & $2.04 \pm 0.12$ & 5.70 & $101.9 \pm 5.8$ & 2.0 \\
& 4.00 & $4.08 \pm 0.13$ & 3.08 & $101.9 \pm 3.1$ & 2.0 \\
\hline
\end{tabular}

\footnotetext{
* three determinations; $\mathrm{CV}=$ coefficient of variation; $\mathrm{sd}=$ standard deviation
} 
not detected in any sample when analyzed by the two methods.

The ratio of chloroform concentrations detected by both validated methods (mean of 20 samples) was $1.13 \pm$ 0.09 with a coefficient of variation of $8.27 \%$. The limit of quantification (LOQ) found for chloroform when Method 1 was used was $1.37 \mu \mathrm{g} / \mathrm{L}$. For method 2 it was $0.74 \mu \mathrm{g} / \mathrm{L}$ (Table V).

The same parameters were $0.93 \pm 0.15$ with a CV of $16.41 \%$ for bromodichloromethane. The limits of quantification were $3.90 \mu \mathrm{g} / \mathrm{L}$ for Method 1 and $0.40 \mu \mathrm{g} / \mathrm{L}$ for Method 2. It can be observed that $50 \%$ of all BDCM concentrations when ECD method was used are lower than the LOQ.

For dibromochloromethane the mean value of the ratios was $0.92 \pm 0.17$ for a $\mathrm{CV}$ of $18.32 \%$. LOQ values for ECD and ELCD methods are $2.26 \mu \mathrm{g} / \mathrm{L}$ and $0.70 \mu \mathrm{g} / \mathrm{L}$ respectively. When ECD method was used to analyze the samples $70 \%$ of the results were lower than the LOQ.

The Brazilian legislation on drinking water quality as well as in many other countries proposes the determination of THM and the expression of the results in terms of the sum of the concentrations of the four compounds known as total trihalomethanes (THMt).

The sum of the results of each THM in the samples, analyzed by both methods and the ratio ECD/ELCD are expressed in Table VI. A ratio of $1.08 \pm 0.05$ and a CV of $4.43 \%$ indicate that both methods can be considered equivalent

This way the choice of the analytical method is a matter of availability of the equipment. Electron capture detection is much easier to be found in any laboratory and is not so much time consuming as ELCD. On the other hand in the ELCD method liquid-liquid extraction is not necessary avoiding the analyst to be exposed to organic solvents.

TABLE V - Trihalomethanes (CF, BDCM and DBCM) determined in 20 samples of drinking water of different sources by ECD and ELCD methods

\begin{tabular}{|c|c|c|c|c|c|c|c|c|c|}
\hline \multirow[t]{2}{*}{ Sample } & \multicolumn{3}{|c|}{ Chloroform $(\mu \mathrm{g} / \mathrm{L})$} & \multicolumn{3}{|c|}{ Bromodichloromethane } & \multicolumn{3}{|c|}{ Dibromochloromethane } \\
\hline & ECD & \multicolumn{2}{|c|}{$\mathrm{ECD} / \mathrm{ELCD}$} & \multicolumn{4}{|c|}{$\mathrm{ECD} / \mathrm{ELCD}$} & \multicolumn{2}{|c|}{$\mathrm{ECD} / \mathrm{ELCD}$} \\
\hline 01 & 67.2 & 61.5 & 1.093 & 17.4 & 15.5 & 1.122 & 2.96 & 3.51 & 0.843 \\
\hline 02 & 74.4 & 70.0 & 1.063 & 17.0 & 15.9 & 1.069 & 3.00 & 3.54 & 0.847 \\
\hline 03 & 75.5 & 76.1 & 0.992 & 18.3 & 17.0 & 1.076 & 3.11 & 3.91 & 0.795 \\
\hline 04 & 82.3 & 74.9 & 1.099 & 17.1 & 16,0 & 1.069 & 3.07 & 3.62 & 0.848 \\
\hline 05 & 73.5 & 56.2 & 1.308 & 7.94 & 8.05 & 0.986 & 1.05 & 1.24 & 0.847 \\
\hline 06 & 20.5 & 19.1 & 1.132 & 1.70 & 2.07 & 0.821 & 0.35 & 0.31 & 1.129 \\
\hline 07 & 72.7 & 51.7 & 1.406 & 13.3 & 13.2 & 1.007 & 5.34 & 3.61 & 1.479 \\
\hline 08 & 27.9 & 26.0 & 1.073 & 3.50 & 4.34 & 0.806 & 0.59 & 0.67 & 0.880 \\
\hline 09 & 25.3 & 24.1 & 1.050 & 3.34 & 4.35 & 0.786 & 0.57 & 0.71 & 0.803 \\
\hline 10 & 22.1 & 19.2 & 1.151 & 3.07 & 3.65 & 0.841 & 0.49 & 0.49 & 1.000 \\
\hline 11 & 22.3 & 19.2 & 1.161 & 3.60 & 4.29 & 0.839 & 0.61 & 0.72 & 0.847 \\
\hline 12 & 26.9 & 25.2 & 1.067 & 3.70 & 4.28 & 0.864 & 0.58 & 0.52 & 1.115 \\
\hline 13 & 26.4 & 23.6 & 1.119 & 3.30 & 3.97 & 0.831 & 0.59 & 0.65 & 0.908 \\
\hline 14 & 25.6 & 23.0 & 1.113 & 3.00 & 3.73 & 0.804 & 0.56 & 0.59 & 0.949 \\
\hline 15 & 28.6 & 24.2 & 1.182 & 3.25 & 3.92 & 0.829 & 0.57 & 0.56 & 1.018 \\
\hline 16 & 86.7 & 73.0 & 1.188 & 21.1 & 15.6 & 1.352 & 3.30 & 4.19 & 0.787 \\
\hline 17 & 80.6 & 78.2 & 1.031 & 19.0 & 18.1 & 1.050 & 3.02 & 4.24 & 0.712 \\
\hline 18 & 49.3 & 42.1 & 1.171 & 5.06 & 5.55 & 0.912 & 0.72 & 0.85 & 0.847 \\
\hline 19 & 26.0 & 22.5 & 1.156 & 2.74 & 3.65 & 0.751 & 0.50 & 0.59 & 0.848 \\
\hline 20 & 37.3 & 32.2 & 1.158 & 4.44 & 5.16 & 0.806 & 0.73 & 0.74 & 0.986 \\
\hline Mean & & & 1.13 & & & 0.93 & & & 0.92 \\
\hline $\mathrm{SD}$ & & & 0.09 & & & 0.15 & & & 0.17 \\
\hline $\mathrm{CV} \%$ & & & 8.27 & & & 16.41 & & & 18.32 \\
\hline
\end{tabular}

$\mathrm{SD}=$ standard deviation; $\mathrm{CV}=$ coefficient of variation 
TABLE VI - Concentrations of total trihalomethanes (THMt) determined in drinking water by both techniques and the ratios ECD/ELCD found .

\begin{tabular}{|c|c|c|c|}
\hline \multirow[b]{2}{*}{ Sample } & \multicolumn{2}{|c|}{ Concentration of tTAM mg/L } & \multirow{2}{*}{$\begin{array}{c}\text { Ratio } \\
\text { ECD/ELCD }\end{array}$} \\
\hline & ECD & ELCD & \\
\hline 01 & 87.6 & 80.5 & 1.088 \\
\hline 02 & 94.4 & 89.4 & 1.056 \\
\hline 03 & 96.9 & 97.0 & 0.999 \\
\hline 04 & 102 & 95.5 & 1.079 \\
\hline 05 & 73.5 & 65.5 & 1.122 \\
\hline 06 & 22.5 & 20.5 & 1.097 \\
\hline 07 & 72.7 & 68.5 & 1.061 \\
\hline 08 & 32.0 & 31.0 & 1.032 \\
\hline 09 & 29.2 & 29.2 & 1.000 \\
\hline 10 & 25.7 & 23.3 & 1.103 \\
\hline 11 & 26.5 & 24.2 & 1.095 \\
\hline 12 & 31.2 & 30.0 & 1.040 \\
\hline 13 & 30.3 & 28.2 & 1.074 \\
\hline 14 & 29.2 & 27.3 & 1.069 \\
\hline 15 & 32.4 & 28.7 & 1.129 \\
\hline 16 & 111 & 92.8 & 1.196 \\
\hline 17 & 103 & 100 & 1.030 \\
\hline 18 & 55.1 & 48.5 & 1.136 \\
\hline 19 & 29.2 & 26.7 & 1.094 \\
\hline 20 & 42.4 & 38. & 1.113 \\
\hline Mean & & & 1.08 \\
\hline SD & & & 0.047 \\
\hline $\mathrm{CV} \%$ & & & 4.43 \\
\hline
\end{tabular}

In the validation and comparison of these two methods all the possibilities of use were not exhaustively studied. The equivalence of both and the advantages that each one may present were stressed.

\section{RESUMO}

\section{Comparação de dois métodos cromatográficos} validados para a dosagem de trialometanos em água potável

São comparados dois métodos cromatográficos validados para a determinação de trialometanos (clorofórmio, bromodiclorometano, dibromoclometano e bromofórmio) em água potável. Os métodos cromatográficos de fase gasosa, a saber: com detetor de captura de elétrons precedido de extração líquido-líquido e com detetor de condutibilidade eletrolítica com "purge and trap" foram comparados em termos de sensibilidade, precisão e recu- peração. O estudo demonstrou que os resultados dos dois procedimentos são equivalentes apresentando as mesmas vantagens quando comparados.

UNITERMOS: Trialometanos. Detecção por Cromatografia A Gás. Comparação de Métodos. Água potável.

\section{REFERENCES}

AMERICAN PUBLIC HEALTH ASSOCIATION Standard methods for the examination of water and wastewater. 19. ed. Washington: APHA, AWWA, WEF, 1995.

BULL, R. J. Health effects of drinking water disinfectants and disinfectant by-products. Environ. Sci .Technol., Washington, v.16, n.10, p.554-559,1982.

CAUSON, R. Validation of chromatographic methods in biomedical analysis-viewpoint and discussion. $J$. Chromatogr., Amsterdam, v.689, p.175-80, 1997.

CECH, I.; HOLGUIN, A.H.; LITTEL, A.S.; HENRY, J.P.; O'CONNELL, J. Health significance of chlorination byproducts in drinking water: the Houston experience. Int. J. Epidemiol., London, v.16, n.2, p.11198-207,1987.

CRAUN, G. F. Epidemiology studies of water disinfectants and disinfection by-products. In: CRAUN, G.F., ed. Safety of water disinfection: balancing chemical and microbial risks. Washington: ILSI Press, 1993. p.277301.

DYCHDALA, G. R. Chlorine and chlorine compounds. In: BLOCK, S.S., ed. Disinfection, sterilization and preservation. 3.ed. Philadelphia: Lea \& Febiger, 1983. p.157-82.

HO, J. S. Volatile organic compounds in water by purge and trap capillary column gas chromatography with photoionization and electrolytic conductivity detectors in series ( Method 502.2 rev.2.0) In: UNITED STATES ENVIRONMENTAL PROTECTION AGENCY (USEPA). Methods for the determination of organic compounds in drinking water. Cincinnati: EPA, 1988. n. p. [ EPA 600/4-88/039 ].

MENZER, R. E Water and soil pollutants. In: AMDUR, M. O.; DOULL, J.; KLAASSEN, C. D., eds. Casaret and Doull's toxicology: the basic science of poisons. 4 ed. New York: Pergamon, 1991. p. 872-902. 
MILLER J. C.; MILLER, J. N. Statistics for analytical chemistry. 2.ed. Cichester: Ellis Harwood, 1988. 227p.

OLIVER, B. G. Analysis of volatile halogenated and purgeable organics. In: AFGHAN, B.K.; CHAU, A.S.Y., eds. Analysis of trace organics in the aquatic environment. Boca Raton: CRC Press, 1989. p.1-29.

PAGE, T.; HARRIS, R. H.; EPSTEIN, S. S. Drinking water and cancer mortality in Louisiana. Science, Washington, v.193, n.4247, p.55-7, 1976.

PONTIUS, F. W. Expedite microbial/disinfection byproducts rules. $J$. $A W W A$, Denver, v.89, n.9, p.20$24,1997$.

RICHARDSON, M. L. Risk assesment of chemicals in the environment. Cambridge: Royal Society of Chemistry, 1988. 579p.

RIEDEL, G. Controle sanitário dos alimentos. 2.ed. São Paulo: Atheneu, 1992.320p.

SINGER, P. C. Formation and characterization of disinfection by-products. In: CRAUN, G. F., ed. Safety of water disinfection: balancing chemical and microbial risks. Washington: ILSI Press, 1993. p.201-219.
TOMINAGA, M. Y., MÍDIO, A. F. Exposição humana a trialometanos presentes em água tratada. Rev. Saúde Pública, São Paulo, v.33. n.4, p. 413-421, 1999.

UNITED STATES ENVIRONMENTAL PROTECTION AGENCY (USEPA). The analysis of trihalomethanes in drinking water by liquid-liquid extraction. Cincinnati: EPA, 1979. n. p. [Method 501.2].

WANG, R. G. M. Water contamination and health. New York: Marcel Dekker, 1994. 524p.

WORLD HEALTH ORGANIZATION. Chloroform. Geneva: WHO, 1994. 174 p. [ Environmental Health Criteria, n.163].

WORLD HEALTH ORGANIZATION. Guidelines for drinking water quality. 2.ed. Geneva: WHO, 1993. v.1. $188 \mathrm{p}$.

WORLD HEALTH ORGANIZATION. Guidelines for drinking water quality. 2.ed. Geneva: WHO, 1996. v.2.p. 849-872.

YOUNG, T. B.; WOLF, D. A.; KANAREK, M. S. Casecontrol study of colon cancer and drinking water trihalomethanes in Wiscosin. Int. J. Epidemiol., London, v.16, n.2, p.190-197, 1987.

Recebido para publicação em 08 de agosto de 2002. 